\title{
Relationship Between 18F-fluorodeoxyglucose Uptake on Positron Emission Tomography and Aortic Calcification
}

\section{Yuriko Okamura}

Toho University: Toho Daigaku

Rine Nakanishi ( $\nabla$ rine.n@med.toho-u.ac.jp )

Toho University: Toho Daigaku https://orcid.org/0000-0002-1429-7429

Hidenobu Hashimoto

Toho University: Toho Daigaku

Kyoko Ota

Toho University: Toho Daigaku

\section{Ryo Okubo}

Toho University: Toho Daigaku

\section{Takayuki Yabe}

Toho University: Toho Daigaku

\section{Ryota Noike}

Toho University: Toho Daigaku

\section{Sunao Mizumura}

Toho University: Toho Daigaku

\section{Kazuma Kishi}

Toho University: Toho Daigaku

\section{Sakae Homma}

Toho University: Toho Daigaku

\section{Takanori Ikeda}

Toho University: Toho Daigaku

\section{Research Article}

Keywords: Atherosclerosis, 18F-fluorodeoxyglucose positron emission tomography, coronary calcium score, thoracic calcium

Posted Date: January 3rd, 2022

DOI: https://doi.org/10.21203/rs.3.rs-1202858/v1 
License: (c) (i) This work is licensed under a Creative Commons Attribution 4.0 International License. Read Full License 


\section{Abstract}

Introduction

Although ${ }^{18} \mathrm{~F}$-fluorodeoxyglucose (FDG) positron emission tomography (PET) has been widely utilized to assess the extent of inflammation, the association between the extent and severity of atherosclerosis and ${ }^{18} \mathrm{~F}$-FDG uptake on PET remains unexamined. The current study aimed to investigate whether aortic calcium (AC) scores were associated with increased aortic uptake of ${ }^{18}$ F-FDG on PET.

Methods

A total of 167 consecutive patients with suspected lung cancer but unproven malignancy who underwent non-contrast-enhanced computed tomography (CT) and ${ }^{18}$ F-FDG PET/CT were enrolled. The average standardized uptake values in the ascending aorta was used to calculate the target-to-background ratio (Mean TBR). The total (thoracic and abdominal) AC scores were measured on non-contrast-enhanced chest and abdominal CT using the Agatston method, and were categorized into three groups $(0,1-399$, and $\geq 400$ ). The relationship between total AC scores and ${ }^{18} \mathrm{~F}$-FDG uptake in the ascending aorta was assessed using multivariate linear regression analysis.

Results

In total, $68.26 \%$ were male, and a mean age was $67.10 \pm 14.70$ years. Mean TBR values increased progressively with total $A C$ score $0,1-399$, and $\geq 400(1.01 \pm 0.07,1.08 \pm 0.09$, and $1.11 \pm 0.11$, respectively; $p<0.00001)$. Multivariate linear regression analysis revealed that increased total AC scores of $1-399$ $(\beta=0.06,95 \% \mathrm{Cl}: 0.01-0.11, p=0.02)$ and $\geq 400(\beta=0.11,95 \% \mathrm{Cl}: 0.06-0.16, p<0.001)$ were significantly associated with higher Mean TBR.

\section{Conclusions}

The current study demonstrated that total AC scores were associated with Mean TBR. Patients with a greater extent and severity of aortic calcifications may possess increased atherosclerotic inflammatory activity as measured by ${ }^{18} \mathrm{~F}-\mathrm{FDG} \mathrm{PET} / \mathrm{CT}$.

\section{Introduction}

Atherosclerosis, a chronic disease of the arterial wall, remains one of the leading causes of mortality worldwide. Estimates show that coronary heart disease will become the largest cause of disability and death globally in the future [1]. Various studies are currently being conducted to provide clear evidence regarding the importance of processes such as lipoprotein oxidation, inflammation, and immunity in human atherosclerosis. Inflammation has been long known as a risk factor for developing atherosclerosis, with recent studies highlighting it as a target marker for the treatment of atherosclerosis apart from cholesterol control [2-4] given the approximately $15-20 \%$ additional risk reduction $[3,5,6]$. 
Coronary artery and aortic calcification have been surrogate markers of atherosclerosis, the severities of which have been associated with the risk of cardiovascular disease [7-9]. However, recent evidence has emerged suggesting that calcification occurs during the late stage of atherosclerosis and may not capture the early stages of the disease. Therefore, no definite conclusions have been established regarding the association between calcification and inflammatory activity.

The current study aimed to investigate whether the calcium score of arteries measured via thoracoabdominal plain computed tomography (CT) was associated with arterial accumulation of ${ }^{18} \mathrm{~F}$ fluorodeoxyglucose (FDG) on positron emission tomography (PET)/CT among patients without cancer.

\section{Materials And Methods}

\section{Study population}

Between February 2015 and September 2017, 1157 patients with suspected lung cancer underwent noncontrast-enhanced chest and abdominal CT and ${ }^{18}$ F-FDG PET examination within 6 months at our institute (Toho University Omori Medical Center, Tokyo, Japan). Among such patients, the following were sequentially excluded: patients with diagnosed lung cancer $(n=926)$, any other malignancies $(n=53)$, strong lymph node accumulation $(n=9)$, and a history of thoracic or abdominal endovascular aortic repair $(n=2)$. Ultimately, the current study enrolled 167 patients (Fig.1), the medical records of whom were then retrospectively reviewed. Our study protocol was approved by the ethics committee of Toho University Omori Medical Center (Ethics approval number: M18020). An opt-out form was uploaded on the website of Toho University Omori Medical Center to inform patients regarding the option to exclude their information from this study.

\section{Scanning and imaging protocol for non-contrastenhanced chest and abdominal CT}

Non-contrast-enhanced chest and abdominal CT was performed using four CT scanners (SOMATOM Definition Flash CT scanner, SIEMENS; SOMATOM Definition AS+ CT scanner, SIEMENS; SOMATOM Definition Edge CT scanner, SIEMENS; and Light Speed VCT VISION, General Electric Healthcare). Patients were scanned without electrocardiographic gating. The slice thickness was $5 \mathrm{~mm}$, while the rotation speed was $0.5 \mathrm{~s} /$ rot. The volume of the computed tomography dose index (CTDIvol) and the dose-lengthproduct were 5-7 mGy and 180-290 mGy·cm, respectively.

\section{Scanning and imaging protocol for ${ }^{18} \mathrm{~F}-\mathrm{FDG}$ PET/CT}

All patients underwent ${ }^{18} \mathrm{~F}$-FDG PET/CT on a BIOGRAPH mCT Flow 20 PET/CT scanner (SIEMENS). Before scanning, participants were required to fast for at least $5 \mathrm{~h}$ and maintain a glucose level of 150 $\mathrm{mg} / \mathrm{mL}$ or lower. Patients were instructed to avoid intense exercise the day before the exam. ${ }^{18} \mathrm{~F}-\mathrm{FDG}$ was administered at approximately $209 \mathrm{MBq}$. Patients were instructed to void before starting imaging. Approximately 60 min after ${ }^{18} \mathrm{~F}-\mathrm{FDG}$ administration, imaging in 3D-mode was initiated. Patients were imaged in the supine position, and CT scanning (100 mAs, $120 \mathrm{kV})$ was conducted before PET imaging. 
The slice thickness was $3 \mathrm{~mm}$. The CT-based attenuation correction technique was used on PET data. A model-based scatter correction for PET was performed and then reoriented in axial, sagittal, and coronal slices.

\section{Imaging analysis of non-contrast-enhanced chest and abdominal CT}

Image analysis of AC scores was performed on a dedicated workstation (IntelliSpace Portal, PHILIPS). Ascending $A C$, descending $A C$, and coronary artery calcium (CAC) scores were measured using the Agatston method [10]. AC scoring was performed using methods described by Agatston et al. on both scan types. Total AC scores were determined by adding the AC scores for each slice.

\section{Imaging analysis of ${ }^{18} \mathrm{~F}-\mathrm{FDG}$ PET/CT}

An automated program (SYNAPSE VINSENT V5.3; FUJI FILM Co. Ltd.) was used to measure standardized uptake values (SUV). This software can display CT and PET images on top of each other, as well as surrounding blood vessels, and measure SUV (Fig.2). Mean ${ }^{18}$ F-FDG uptake on PET/CT using the SUV

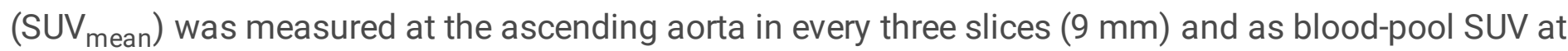
the superior vena cava (SVC) in one slice at the level of the pulmonary artery bifurcation (SVC $S U V_{\text {mean }}$ ). The average SUV mean value (Mean SUV) in the ascending aorta was used to calculate the target-to-background ratio (Mean TBR) [Mean SUV / (SVC - SUV mean $_{\text {)]. }}$

\section{Comparison of SUV values measured over the entire ascending aorta and limited areas thereof}

This study calculated 530 slices of the entire aorta from 5 randomly selected patients in order to compare the SUV $V_{\text {mean }}$ at the entire aorta to that measured at the ascending or descending aorta in every three

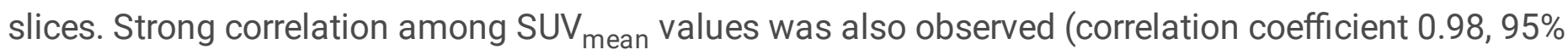
confidence interval 0.87-0.99, $p<0.001$ ). Considering the high concordance, our analyses therefore included the SUV values at the ascending aorta in every three slices.

\section{Statistical analysis}

Continuous variables were expressed as mean $\pm S D$, whereas categorical variables were expressed as frequencies or percentages. Total AC score and CAC score were categorized into three groups $(0,1-399$, and $\geq 400$ ). The Mann-Whitney $U$ test was performed to determine whether the total AC score was associated with clinical risk factors. SUV and TBR values were compared between total AC score and CAC score groups using one-way analysis of variance or the Kruskal-Wallis test. Mean TBR values were compared between the total AC score or CAC score groups stratified according to C-reactive protein (CRP) and low-density lipoprotein cholesterol. Multivariate linear regression analysis was used to assess whether the total AC score, including thoracic and abdominal AC or CAC scores, was associated with ${ }^{18} \mathrm{~F}$ FDG uptake on PET in the ascending aorta after adjusting for age, gender, body mass index (BMI), history of coronary artery disease (CAD), diabetes mellitus (DM), dyslipidemia (DL), hypertension (HT), and CRP 
value. All analyses were conducted using STATA (Version 11, Stata Corp LP, College Station, Texas, USA), with a $p$ value of $<0.05$ indicating statistical significance.

\section{Results}

The baseline characteristics of the study population are listed in Table 1. Accordingly, the included patients, $68.26 \%$ of whom were male, had a mean age of $67.10 \pm 14.70$ years and a mean BMI of $21.90 \pm$ $3.70 \mathrm{~kg} / \mathrm{m}^{2}$. Clinical CAD risk factors, such as $\mathrm{HT}$, DL, and DM, were present in $28.74 \%, 11.98 \%$, and $11.98 \%$ of the patients, respectively. Approximately half of patients were smokers, while $17.37 \%$ were current smokers. Compared to patients with a total AC score of 0 , those with the total AC score of 1-399 and $\geq 400$ were older and had greater rates of $\mathrm{HT}$ and history of CAD. Regarding the laboratory data, CRP and blood glucose levels were significantly increased in patients with a higher total AC score $(<0.001$ for all), whereas no significant differences in other laboratory data were noted between the three groups. 
Table 1

Baseline characteristics of the study population.

Total

Total AC score

$P$

value

Number of patients
Clinical demographics

\begin{tabular}{|c|c|c|c|c|c|}
\hline Age (years, mean \pm SD) & $\begin{array}{l}67.10 \pm \\
14.70\end{array}$ & $\begin{array}{l}51.23 \pm \\
16.74\end{array}$ & $\begin{array}{l}60.28 \pm \\
14.66^{*}\end{array}$ & $\begin{array}{l}74.22 \pm \\
7.44^{\star}, \star \star\end{array}$ & $<0.001$ \\
\hline Male gender (n, \%) & $114(68.26)$ & $20(66.67)$ & $23(63.89)$ & $71(70.30)$ & $<0.001$ \\
\hline Height (cm) & $1.62 \pm 0.10$ & $\begin{array}{l}1.662 \pm \\
0.09\end{array}$ & $1.63 \pm 0.11$ & $1.61 \pm 0.09 *$ & 0.03 \\
\hline Body Weight (kg) & $\begin{array}{l}57.80 \pm \\
12.60\end{array}$ & $\begin{array}{l}63.16 \pm \\
17.28\end{array}$ & $\begin{array}{l}56.94 \pm \\
15.26\end{array}$ & $\begin{array}{l}55.97 \pm \\
10.74^{\star}\end{array}$ & 0.16 \\
\hline $\mathrm{BMI}\left(\mathrm{kg} / \mathrm{m}^{2}\right.$, mean $\left.\pm \mathrm{SD}\right)$ & $\begin{array}{l}21.90 \pm \\
3.70\end{array}$ & $\begin{array}{l}22.64 \pm \\
4.73\end{array}$ & $\begin{array}{l}21.96 \pm \\
3.21\end{array}$ & $21.55 \pm 3.50$ & 0.36 \\
\hline Hypertension (n, \%) & $48(28.74)$ & $4(13.33)$ & $4(11.11)$ & $\begin{array}{l}40 \\
(39.60) *, \star *\end{array}$ & $<0.001$ \\
\hline Dyslipidemia (n, \%) & 20 (11.98) & $3(10.00)$ & $1(2.78)$ & $16(15.84)^{\star \star}$ & 0.11 \\
\hline Diabetes mellitus (n, \%) & 20 (11.98) & $2(6.67)$ & $2(5.56)$ & $16(15.84)$ & 0.16 \\
\hline $\begin{array}{l}\text { History of coronary artery } \\
\text { disease }(n, \%)\end{array}$ & $14(8.38)$ & $0(0.0)$ & $1(2.78)$ & $13(12.87)^{\star}$ & 0.03 \\
\hline Current smoker $(\mathrm{n}, \%)$ & $29(17.37)$ & $6(20.00)$ & $9(25.00)$ & $14(13.86)$ & 0.29 \\
\hline Past smoker (n, \%) & $81(48.50)$ & $12(40.00)$ & $16(44.44)$ & $53(52.48)$ & 0.42 \\
\hline Never smoker (n, \%) & $57(34.13)$ & $13(43.33)$ & $12(33.33)$ & 35 (34.65) & 0.64 \\
\hline \multicolumn{6}{|l|}{ Laboratory data } \\
\hline $\mathrm{CRP}(\mathrm{mg} / \mathrm{dl}$, mean $\pm \mathrm{SD})$ & $1.68 \pm 0.60$ & $0.32 \pm 0.51$ & $0.36 \pm 0.59$ & $0.76 \pm 2.10$ & $<0.001$ \\
\hline $\mathrm{BUN}(\mathrm{mg} / \mathrm{dl}$, mean $\pm \mathrm{SD})$ & $\begin{array}{l}15.67 \pm \\
6.50\end{array}$ & $\begin{array}{l}14.07 \pm \\
4.56\end{array}$ & $\begin{array}{l}13.94 \pm \\
4.00\end{array}$ & $\begin{array}{l}16.74 \pm \\
7.48^{\star \star}\end{array}$ & 0.11 \\
\hline $\begin{array}{l}\text { Creatinine }(\mathrm{mg} / \mathrm{dL} \text {, mean } \pm \\
\text { SD) }\end{array}$ & $0.88 \pm 0.61$ & $0.79 \pm 0.24$ & $0.76 \pm 0.18$ & $0.95 \pm 0.75$ & 0.22 \\
\hline
\end{tabular}

$\star \mathrm{P}<0.05$ compared to Total AC score $=\mathbb{\nabla} ; * \star \mathrm{P}<0.05$ compared to Total AC score $=1-399$

Abbreviations: AC, aortic calcium; BMI, body mass index; CRP, C-reactive protein; BUN, blood urea nitrogen; HDL-C, high-density lipoprotein cholesterol; LDL-C, low-density lipoprotein cholesterol; LDH, lactate dehydrogenase; CEA, carcinoembryonic antigen; KL-6, sialylated carbohydrate antigen; NSE, neuron-specific enolase; ProGRP, pro-gastrin-releasing peptide 


\begin{tabular}{|c|c|c|c|c|c|}
\hline \multirow[b]{2}{*}{$\begin{array}{l}\text { Blood glucose level (mg/dL, } \\
\text { mean } \pm \text { SD) }\end{array}$} & \multirow{2}{*}{$\begin{array}{l}\text { Total } \\
\begin{array}{l}117.91 \pm \\
36.89\end{array}\end{array}$} & \multicolumn{3}{|c|}{ Total AC score } & \multirow{2}{*}{$\begin{array}{l}\mathrm{P} \\
\text { value } \\
<0.001\end{array}$} \\
\hline & & $\begin{array}{l}104.00 \pm \\
13.92\end{array}$ & $\begin{array}{l}107.69 \pm \\
25.80\end{array}$ & $\begin{array}{l}125.58 \pm \\
42.53^{\star}, \star \star \star\end{array}$ & \\
\hline $\begin{array}{l}\text { Hemoglobin A1c }(\% \text {, mean } \pm \\
\text { SD) }\end{array}$ & $5.93 \pm 0.76$ & $5.88 \pm 0.90$ & $5.74 \pm 0.55$ & $6.00 \pm 0.77$ & 0.28 \\
\hline $\begin{array}{l}\text { Total cholesterol }(\mathrm{mg} / \mathrm{dL} \text {, } \\
\text { mean } \pm \mathrm{SD})\end{array}$ & $\begin{array}{l}191.61 \pm \\
39.93\end{array}$ & $\begin{array}{l}185.92 \pm \\
32.01\end{array}$ & $\begin{array}{l}202.63 \pm \\
38.17\end{array}$ & $\begin{array}{l}189.76 \pm \\
41.99\end{array}$ & 0.22 \\
\hline $\begin{array}{l}\text { Triglyceride }(\mathrm{mg} / \mathrm{dL} \text {, mean } \pm \\
\text { SD) }\end{array}$ & $\begin{array}{l}120.47 \pm \\
81.73\end{array}$ & $\begin{array}{l}110.69 \pm \\
76.78\end{array}$ & $\begin{array}{l}123.94 \pm \\
91.57\end{array}$ & $\begin{array}{l}121.99 \pm \\
80.21\end{array}$ & 0.80 \\
\hline $\mathrm{HDL}-\mathrm{C}(\mathrm{mg} / \mathrm{dL}$, mean $\pm \mathrm{SD})$ & $\begin{array}{l}59.97 \pm \\
19.08\end{array}$ & $\begin{array}{l}54.83 \pm \\
18.39\end{array}$ & $\begin{array}{l}63.08 \pm \\
20.58\end{array}$ & $\begin{array}{l}60.53 \pm \\
18.74\end{array}$ & 0.29 \\
\hline $\mathrm{LDL}-\mathrm{C}(\mathrm{mg} / \mathrm{dL}$, mean $\pm \mathrm{SD})$ & $\begin{array}{l}113.13 \pm \\
33.20\end{array}$ & $\begin{array}{l}111.46 \pm \\
23.30\end{array}$ & $\begin{array}{l}124.31 \pm \\
30.09\end{array}$ & $\begin{array}{l}110.19 \pm \\
35.94^{\star \star}\end{array}$ & 0.10 \\
\hline $\mathrm{LDH}(\mathrm{U} / \mathrm{L}$, mean $\pm \mathrm{SD})$ & $\begin{array}{l}216.27 \pm \\
59.10\end{array}$ & $\begin{array}{l}222.97 \pm \\
69.30\end{array}$ & $\begin{array}{l}213.46 \pm \\
39.12\end{array}$ & $\begin{array}{l}215.26 \pm \\
61.73\end{array}$ & 0.83 \\
\hline CEA $(\mathrm{ng} / \mathrm{ml}$, mean $\pm \mathrm{SD})$ & $\begin{array}{l}5.97 \pm \\
26.00\end{array}$ & $2.30 \pm 2.23$ & $2.64 \pm 2.38$ & $\begin{array}{l}7.331 \pm \\
32.83\end{array}$ & $<0.001$ \\
\hline $\mathrm{KL}-6(\mathrm{U} / \mathrm{ml}$, mean $\pm \mathrm{SD})$ & $\begin{array}{l}424.90 \pm \\
708.50\end{array}$ & $\begin{array}{l}325.64 \pm \\
292.95\end{array}$ & $\begin{array}{l}311.54 \pm \\
184.55\end{array}$ & $\begin{array}{l}486.99 \pm \\
868.46\end{array}$ & 0.18 \\
\hline NSE $(n g / m L$, mean \pm SD) & $\begin{array}{l}11.56 \pm \\
5.40\end{array}$ & $\begin{array}{l}10.26 \pm \\
2.76\end{array}$ & $\begin{array}{l}12.67 \pm \\
6.54\end{array}$ & $11.60 \pm 5.48$ & 0.17 \\
\hline ProGRP $(\mathrm{pg} / \mathrm{mL}$, mean $\pm \mathrm{SD})$ & $\begin{array}{l}47.79 \pm \\
22.50\end{array}$ & $\begin{array}{l}39.84 \pm \\
16.25\end{array}$ & $\begin{array}{l}48.11 \pm \\
24.46\end{array}$ & $\begin{array}{l}50.07 \pm \\
23.21^{*}\end{array}$ & 0.01 \\
\hline
\end{tabular}

$\star \mathrm{P}<0.05$ compared to Total AC score $=\mathbb{\nabla} ; * \star \mathrm{P}<0.05$ compared to Total AC score $=1-399$

Abbreviations: AC, aortic calcium; BMI, body mass index; CRP, C-reactive protein; BUN, blood urea nitrogen; HDL-C, high-density lipoprotein cholesterol; LDL-C, low-density lipoprotein cholesterol; LDH, lactate dehydrogenase; CEA, carcinoembryonic antigen; KL-6, sialylated carbohydrate antigen; NSE, neuron-specific enolase; ProGRP, pro-gastrin-releasing peptide

${ }^{18}$ F-FDG PET/CT data from 167 patients showed that Mean TBR, Max TBR, Mean SUV, and Max SUV were $1.08 \pm 0.10,1.10 \pm 0.10,1.69 \pm 0.33$, and $2.34 \pm 0.47$, respectively. Table 2 compares the Mean and Max TBR and Mean and Mean SUV values between the total AC groups and CAC score groups. Compared to those with a total AC score of 0 , those with a total AC score of 1-399 and $\geq 400$ had progressively greater Mean TBR values. However, such a relationship was not observed between patients with a CAC score of $0,1-399$, and $\geq 400$. 
Table 2

Comparison of calcium scores for each artery with TBR and SUV.

Total AC score $(\mathrm{N}=167)$

\begin{tabular}{|c|c|c|c|c|}
\hline & $\begin{array}{l}0 \\
(N=30)\end{array}$ & $\begin{array}{l}1-399 \\
(N=36)\end{array}$ & $\begin{array}{l}\geq 400 \\
(N=101)\end{array}$ & $P$ value \\
\hline Mean TBR & $1.01 \pm 0.07$ & $1.08 \pm 0.09$ & $1.11 \pm 0.11$ & $<0.001$ \\
\hline Max TBR & $1.07 \pm 0.09$ & $1.10 \pm 0.10$ & $1.11 \pm 0.09$ & 0.13 \\
\hline Mean SUV & $1.73 \pm 0.21$ & $1.67 \pm 0.35$ & $1.69 \pm 0.35$ & 0.56 \\
\hline \multirow[t]{4}{*}{ Max SUV } & $2.39 \pm 0.35$ & $2.30 \pm 0.49$ & $2.34 \pm 0.50$ & 0.74 \\
\hline & \multicolumn{4}{|c|}{ CAC score $(\mathrm{N}=167)$} \\
\hline & 0 & $1-399$ & $\geq 400$ & $P$ value \\
\hline & $(N=101)$ & $(N=45)$ & $(N=21)$ & \\
\hline Mean TBR & $1.08 \pm 0.11$ & $1.08 \pm 0.09$ & $1.07 \pm 0.11$ & 0.79 \\
\hline Max TBR & $1.11 \pm 0.10$ & $1.10 \pm 0.08$ & $1.08 \pm 0.11$ & 0.53 \\
\hline Mean SUV & $1.68 \pm 0.35$ & $1.70 \pm 0.33$ & $1.73 \pm 0.26$ & 0.77 \\
\hline Max SUV & $2.31 \pm 0.49$ & $2.36 \pm 0.44$ & $2.43 \pm 0.49$ & 0.51 \\
\hline
\end{tabular}

Table 3 compares the Mean TBR values between the total AC score groups stratified according to lowdensity lipoprotein cholesterol (LDL-C) and CRP levels. Accordingly, those with a total AC score of 1-399 had higher Mean TBR values compared to those with a total AC score of 0 , with those having a total AC score of $\geq 400$ showing even greater Mean TBR values, regardless of CRP values ( $<0.5$ or $\geq 0.5$ ). Regarding the lower LDL-C values with $<120$, Mean TBR gradually increased with total AC 1-399 and $\geq 400$ compared to total AC score $=0$, and higher Mean TBR was likely to be increased in total AC 1-399 and $\geq 400$ compared to total AC score $=0$ when stratified by LDL-C $\geq 120$. In terms of CAC score, significant increase in Mean TBR was not shown across the CAC groups regardless of CRP and LDL-C levels. 
Table 3

The comparison of Mean TBR values between the total AC score groups stratified according to C-reactive protein and low-density lipoprotein cholesterol.

\begin{tabular}{|c|c|c|c|c|c|}
\hline & & \multicolumn{3}{|c|}{ Total AC score } & \multirow{3}{*}{$P$ value } \\
\hline & & 0 & $1-399$ & $\geq 400$ & \\
\hline & & $(N=30)$ & $(N=36)$ & $(N=101)$ & \\
\hline \multirow{4}{*}{$\begin{array}{l}\text { CRP } \\
(\mathrm{mg} / \mathrm{dl})\end{array}$} & $0-0.5$ & $1.01 \pm 0.08$ & $1.08 \pm 0.07$ & $1.10 \pm 0.11$ & $<0.001$ \\
\hline & & $(\mathrm{N}=25)$ & $(N=29)$ & $(N=75)$ & \\
\hline & $\geq 0.5$ & $1.02 \pm 0.03$ & $1.03 \pm 0.13$ & $1.13 \pm 0.11$ & 0.02 \\
\hline & & $(N=5)$ & $(N=6)$ & $(\mathrm{N}=25)$ & \\
\hline \multirow{7}{*}{$\begin{array}{l}\text { LDL-C } \\
(\mathrm{mg} / \mathrm{dl})\end{array}$} & $<120$ & $1.02 \pm 0.70$ & $1.08 \pm 0.08$ & $1.10 \pm 0.11$ & 0.08 \\
\hline & & $(N=10)$ & $(N=14)$ & $(\mathrm{N}=30)$ & \\
\hline & $\geq 120$ & $1.02 \pm 0.04$ & $1.05 \pm 0.10$ & $1.11 \pm 0.11$ & 0.01 \\
\hline & & $(N=14)$ & $(\mathrm{N}=12)$ & $(N=55)$ & \\
\hline & & CAC score & & & \\
\hline & & 0 & $1-399$ & $\geq 400$ & \\
\hline & & $(N=101)$ & $(N=45)$ & $(N=21)$ & \\
\hline \multirow{4}{*}{$\begin{array}{l}\text { CRP } \\
(\mathrm{mg} / \mathrm{dl})\end{array}$} & $0-0.5$ & $1.09 \pm 0.10$ & $1.07 \pm 0.08$ & $1.05 \pm 0.11$ & 0.35 \\
\hline & & $(\mathrm{N}=81)$ & $(N=32)$ & $(\mathrm{N}=16)$ & \\
\hline & $\geq 0.5$ & $1.08 \pm 0.14$ & $1.13 \pm 0.02$ & $1.12 \pm 0.09$ & 0.40 \\
\hline & & $(\mathrm{N}=19)$ & $(N=12)$ & $(N=5)$ & \\
\hline \multirow{4}{*}{$\begin{array}{l}\text { LDL-C } \\
(\mathrm{mg} / \mathrm{dl})\end{array}$} & $<120$ & $1.08 \pm 0.11$ & $1.10 \pm 0.10$ & $1.07 \pm 0.11$ & 0.58 \\
\hline & & $(N=39)$ & $(N=24)$ & $(\mathrm{N}=16)$ & \\
\hline & $\geq 120$ & $1.09 \pm 0.10$ & $1.06 \pm 0.09$ & $1.06 \pm 0.06$ & 0.57 \\
\hline & & $(\mathrm{N}=44)$ & $(N=9)$ & $(N=3)$ & \\
\hline
\end{tabular}

The relationship between Mean TBR and total AC or CAC score is presented in Table 4. After adjusting for age, sex, $B M I, C A D, D M, D L, H T$, and CRP value, multivariate linear regression analysis revealed that increased total AC scores (1-399 and $\geq 400$ ) were significantly associated with higher Mean TBR compared to total AC score 0 . In contrast, after adjusting for age, sex, BMI, CAD, DM, DL, HT, and CRP 
value, multivariate linear regression analysis revealed that CAC scores of $1-399$, and $\geq 400$ were not significantly associated with Mean TBR.

Table 4

Multivariate linear regression models for the identification of the relationship between Mean TBR and total AC score or CAC score.

\begin{tabular}{|lll|}
\hline & $\boldsymbol{\beta}(95 \% \mathrm{Cl})$ & P value \\
\hline Total AC score & & \\
\hline 0 & $1(\mathrm{REF})$ & 0.02 \\
\hline $1-399$ & $0.06(0.01-0.11)$ & $<0.001$ \\
\hline$\geq 400$ & $0.11(0.06-0.16)$ & \\
\hline CAC score & & 0.17 \\
\hline 0 & $1(\mathrm{REF})$ & 0.047 \\
\hline $1-399$ & $-0.03(-0.07--0.01)$ & \\
\hline$\geq 400$ & $-0.06(-0.12--0.0008)$ & \\
\hline Abbreviations: AC, aortic calcium; CAC, coronary artery calcium; TBR, target-to-background ratio \\
\hline
\end{tabular}

\section{Discussion}

Although the current study demonstrated that the extent and severity of aortic calcifications was associated with increased ${ }^{18} \mathrm{~F}$-FDG uptake on PET, our results showed no association between CAC scores and ${ }^{18} \mathrm{~F}$-FDG uptake. Regardless of CRP and LDL-C levels, those with higher total AC scores exhibited increased ${ }^{18} \mathrm{~F}$-FDG uptake on PET. In theory, vascular calcification and vascular metabolic activity rarely overlap, suggesting that these findings represent different stages of atheroma evolution [11]. While macro-calcifications are thought to occur at the later stages of the atherosclerosis process, global calcifications have been suggested to reflect overall atherosclerosis, including noncalcified and calcified atherosclerosis. Therefore, atherosclerosis in the coronary artery or aorta (i.e., CAC or AC scores) have been associated with higher cardiovascular events or mortality $[8,12,13]$. Numerous studies have evaluated ${ }^{18} \mathrm{~F}$-FDG uptake on PET in vascular inflammation $[14,15]$ and atherosclerotic lesions in patients with cancer, psoriasis, rheumatoid arthritis, and chronic kidney disease, as well as those taking antiinflammatory drugs [11,16-19]. Moreover, limited studies have reported an association between vascular calcifications and inflammation $[20,21]$. However, there is still an ongoing debate regarding the association between calcification, plaque vulnerability, and inflammatory activity in plaque. Our group recently reported that details related to calcified plaque (i.e., calcified density) measured by non-contrastenhanced CT in the coronary artery were associated with optical coherence tomography (OCT)-derived calcified size but not with OCT-derived plaque vulnerability [22]. The aforementioned study emphasized that CT-derived calcium density in local macro-calcifications may not always indicate local plaque 
vulnerability, although the association between calcifications and plaque activity had not been assessed. Similarly, a study of 183 patients showed that those with increased local coronary ${ }^{18} \mathrm{~F}$-Fluoride uptake in at least one coronary artery were likely to have higher overall CAC scores [23]. However, local coronary

${ }^{18} \mathrm{~F}$-Fluoride uptake was not associated with overall CAC progression. Our findings expanded these results by showing that Mean TBR of the aorta reflected the overall extent and severity of atherosclerosis (i.e., total AC scores in the current study). The Mean TBR value of $1.08 \pm 0.10$ in the aorta obtained herein was relatively low compared to that presents in previous studies, which ranged from 1.13 to 1.97 in the carotid and other vascular arteries [20,24-28]. This may have been due to the lower presence of traditional risk factors for $C A D$, such as $H T, D L$, and DM, among our patients. However, no prior study had compared the association between calcification and ${ }^{18} \mathrm{~F}$-FDG uptake on PET in the aorta among low-risk patients. Despite such a lower risk of CAD, the current study observed a significant association between Mean TBR and total AC scores among patients with suspected but undiagnosed lung cancer. Additionally, the association between increased total AC scores and higher Mean TBR values was consistently observed regardless of CRP or LDL-C values. Our findings suggest that ${ }^{18} \mathrm{~F}-\mathrm{FDG}$ PET can be an indicator of imperceptible vasculitis and that the association between ${ }^{18} \mathrm{~F}-\mathrm{FDG}$ uptake on PET and the extent and severity of calcified plaque in the aorta may be consistent regardless of coronary vascular risk, potentially suggesting that ${ }^{18} \mathrm{~F}$-FDG PET can be utilized for the early detection of atherosclerotic activity. Investigating methods for assessing arterial calcification in combination with ${ }^{18} \mathrm{~F}-\mathrm{FDG}$ uptake on PET/CT may provide additional insights into atherosclerosis and facilitate new clinical applications. Moreover, studies investigating the prognostic utility of combined evaluation will be required.

Some limitations of the current study are worth noting. First, this study was a single-center, retrospective study with a relatively small sample size. Second, as noted earlier, our study population comprised patients who underwent ${ }^{18} \mathrm{~F}$-FDG PET/CT due to suspicion of malignant disease. Therefore, the association between ${ }^{18} \mathrm{~F}$-FDG PET and aortic calcifications in patients at higher CAD risk still remains unknown. Third, although several cytokines, such as IL-6, have been associated with ${ }^{18} \mathrm{~F}$-FDG uptake on PET, such variables had not been assessed herein.

\section{Conclusion}

The current study demonstrated that among patients without cancer who underwent ${ }^{18} \mathrm{~F}-\mathrm{FDG} \mathrm{PET}$, the total AC scores were associated with Mean TBR. Patients with greater extent and severity of aortic calcifications may exhibit increased atherosclerotic inflammatory activity as measured by ${ }^{18} \mathrm{~F}$-FDG PET regardless of CAD risks.

\section{Declarations}

\section{Statements \& Declarations}


Funding: The authors declare that no funds, grants, or other support were received during the preparation of this manuscript.

Competing Interests: The authors have no relevant financial or non-financial interests to disclose.

Author Contributions: All authors contributed to the study conception and design. Data collection and analysis were performed by Yuriko Okamura, Rine Nakanishi, Hidenobu Hashimoto, Kyoko Ota, Ryo Okubo, Takayuki Yabe and Ryota Noike. Yuriko Okamura performed the statistical analyses and drafted the manuscript. Sunao Mizumura, Kazuma Kishi, Sakae Homma and Takanori lkeda reviewed and revised the manuscript. All authors read and approved the final manuscript.

Ethics approval: The institutional review board of our institution approved this retrospective study and the requirement for informed consent was waived (M18020) owing to the retrospective nature of this study.

Consent to participate: Requirement of informed consent was waived because this was a retrospective study of medical records.

Consent to publish: Not applicable.

Conflict of interest: The authors have no conflict of interest to declare.

\section{Acknowledgments}

The authors thank the radiologists Mr. Fuyuki Washizuka, Mr. Tadashi Kokubo, and Mr. Nobutomo Ishii for educating us regarding the scanning and imaging protocol.

\section{References}

1. Murray CJ, Lopez AD (1997) Mortality by cause for eight regions of the world: global Burden of Disease Study. Lancet; 349: 1269-1276. https://doi.org/10.1016/S0140-6736(96)07493-4

2. Ridker PM, MacFadyen JG, Thuren T, Libby P (2020) Residual inflammatory risk associated with interleukin-18 and interleukin- 6 after successful interleukin-1 $\beta$ inhibition with canakinumab: further rationale for the development of targeted anti-cytokine therapies for the treatment of atherothrombosis. Eur Heart J 41:2153-2163. https://doi.org/10.1093/eurheartj/ehz542

3. Ridker PM, Everett BM, Thuren T, MacFadyen JG, Chang WH, Ballantyne C, Fonseca F, Nicolau J, Koenig W, Anker SD, Kastelein JJP, Cornel JH, Pais P, Pella D, Genest J, Cifkova R, Lorenzatti A, Forster T, Kobalava Z, Vida-Simiti L, Flather M, Shimokawa H, Ogawa H, Dellborg M, Rossi PRF, Troquay RPT, Libby P, Glynn RJ, CANTOS Trial Group (2017) Antiinflammatory therapy with canakinumab for atherosclerotic disease. N Engl J Med 377:1119-11131. https://doi.org/10.1056/NEJMoa1707914

4. Ridker PM, MacFadyen JG, Glynn RJ, Bradwin G, Hasan AA, Rifai N (2020) Comparison of interleukin-6, C-reactive protein, and low-density lipoprotein cholesterol as biomarkers of residual risk in 
contemporary practice: secondary analyses from the cardiovascular Inflammation Reduction Trial. Eur Heart J ; 41: 2952-2961. https://doi.org/10.1093/eurheartj/ehaa160

5. Ridker PM, MacFadyen JG, Everett BM, Libby P, Thuren T, Glynn RJ, CANTOS Trial Group (2018) Relationship of C-reactive protein reduction to cardiovascular event reduction following treatment with canakinumab: a secondary analysis from the CANTOS randomised controlled trial. Lancet 391:319-328. https://doi.org/10.1016/S0140-6736(17)32814-3

6. Ridker PM, Libby P, MacFadyen JG, Thuren T, Ballantyne C, Fonseca F, Koenig W, Shimokawa H, Everett BM, Glynn RJ (2018) Modulation of the interleukin-6 signalling pathway and incidence rates of atherosclerotic events and all-cause mortality: analyses from the Canakinumab Anti-Inflammatory Thrombosis Outcomes Study (CANTOS). Eur Heart J 39:3499-3507.

https://doi.org/10.1093/eurheartj/ehy310

7. Nakanishi R, Berman DS, Budoff MJ, Gransar H, Achenbach S, Al-Mallah M, Andreini D, Cademartiri F, Callister TQ, Chang HJ, Cheng VY, Chinnaiyan K, Chow BJ, Cury R, Delago A, Hadamitzky M, Hausleiter J, Feuchtner G, Kim YJ, Kaufmann PA, Leipsic J, Lin FY, Maffei E, Pontone G, Raff G, Shaw LJ, Villines TC, Dunning A, Min JK (2015) Current but not past smoking increases the risk of cardiac events: insights from coronary computed tomographic angiography. Eur Heart J 36:1031-1040. https://doi.org/10.1093/eurheartj/ehv013

8. Budoff MJ, Shaw LJ, Liu ST, Weinstein SR, Mosler TP, Tseng PH, Flores FR, Callister TQ, Raggi P, Berman DS (2007) Long-term prognosis associated with coronary calcification: observations from a registry of 25,253 patients. J Am Coll Cardiol 49:1860-1870. https://doi.org/10.1016/j.jacc.2006.10.079

9. Budoff MJ, Nasir K, Katz R, Takasu J, Carr JJ, Wong ND, Allison M, Lima JA, Detrano R, Blumenthal RS, Kronmal R (2011) Thoracic aortic calcification and coronary heart disease events: the multi-ethnic study of atherosclerosis (MESA). Atherosclerosis 215:196-202. https://doi.org/10.1016/j.atherosclerosis.2010.11.017

10. Agatston AS, Janowitz WR, Hildner FJ, Zusmer NR, Viamonte M, Detrano R (1990) Quantification of coronary artery calcium using ultrafast computed tomography. J Am Coll Cardiol 15:827-832. https://doi.org/10.1016/0735-1097(90)90282-t

11. Dunphy MP, Freiman A, Larson SM, Strauss HW (2005) Association of vascular 18F-FDG uptake with vascular calcification. J Nucl Med 46:1278-1284.

12. Raggi P, Callister TQ, Cooil B, He ZX, Lippolis NJ, Russo DJ, Zelinger A, Mahmarian JJ (2000) Identification of patients at increased risk of first unheralded acute myocardial infarction by electronbeam computed tomography. Circulation 101:850-855. https://doi.org/10.1161/01.cir.101.8.850

13. Tota-Maharaj R, Blaha MJ, McEvoy JW, Blumenthal RS, Muse ED, Budoff MJ, Shaw LJ, Berman DS, Rana JS, Rumberger J, Callister T, Rivera J, Agatston A, Nasir K (2012) Coronary artery calcium for the 
prediction of mortality in young adults $<45$ years old and elderly adults $>75$ years old. Eur Heart $\mathrm{J}$ 33:2955-2962. https://doi.org/10.1093/eurheartj/ehs230

14. Kaim AH, Weber B, Kurrer MO, Gottschalk J, Von Schulthess GK, Buck A (2002) Autoradiographic quantification of 18F-FDG uptake in experimental soft-tissue abscesses in rats. Radiology 223:446-451. https://doi.org/10.1148/radiol.2232010914

15. Osman S, Danpure HJ (1992) The use of 2-[18F]fluoro-2-deoxy-D-glucose as a potential in vitro agent for labelling human granulocytes for clinical studies by positron emission tomography. Int J Rad Appl Instrum B 19:183-190. https://doi.org/10.1016/0883-2897(92)90006-k

16. Yun M, Yeh D, Araujo LI, Jang S, Newberg A, Alavi A (2001) F-18 FDG uptake in the large arteries: a new observation. Clin Nucl Med 26:314-319. https://doi.org/10.1097/00003072-200104000-00007

17. Ben-Haim S, Kupzov E, Tamir A, Israel O (2004) Evaluation of 18F-FDG uptake and arterial wall calcifications using 18F-FDG PET/CT. J Nucl Med 45:1816-1821.

18. Rose S, Sheth NH, Baker JF, Ogdie A, Raper A, Saboury B, Werner TJ, Thomas P, Vanvoorhees A, Alavi A, Torigian DA, Gelfand JM, Mehta NN (2013) A comparison of vascular inflammation in psoriasis, rheumatoid arthritis, and healthy subjects by FDG-PET/CT: a pilot study. Am J Cardiovasc Dis 3:273-278.

19. Yoon HE, Kim Y, Kim SD, et al (2018) A pilot trial to examine the changes in carotid arterial inflammation in renal transplant recipients as assessed by 18F-fluorodeoxyglucose (18F-FDG) positron emission tomography computed tomography (PET/CT). Ann Transplant; 23: 412-421.

https://doi.org/10.12659/AOT.909212

20. Joshi FR, Rajani NK, Abt M, Woodward M, Bucerius J, Mani V, Tawakol A, Kallend D, Fayad ZA, Rudd JH (2013) Does vascular calcification accelerate inflammation?: a substudy of the dal-PLAQUE Trial. J Am Coll Cardiol 67:69-78. https://doi.org/10.1016/j.jacc.2015.10.050

21. Nakahara T, Narula J, Fox JJ, Jinzaki M, Strauss HW (2021) Temporal relationship between ${ }^{18} \mathrm{~F}$ sodium fluoride uptake in the abdominal aorta and evolution of CT-verified vascular calcification. J Nucl Cardiol 28:1936-1945. https://doi.org/10.1007/s12350-019-01934-2

22. Okubo R, Nakanishi R, Dailing C, Yabe T, Noike R, Matsumoto S, Aikawa H, Okamura Y, Hashimoto $\mathrm{H}$, Amano H, Toda M, Maehara A, Budoff MJ, Ikeda T (2020) The relationship between coronary artery calcium density and optical coherence tomography-derived plaque characteristics. Atherosclerosis 311:30-36. https://doi.org/10.1016/j.atherosclerosis.2020.08.010

23. Doris MK, Meah MN, Moss AJ, Andrews JPM, Bing R, Gillen R, Weir N, Syed M, Daghem M, Shah A, Williams MC, van Beek EJR, Forsyth L, Dey D, Slomka PJ, Dweck MR, Newby DE, Adamson PD (2020) Coronary ${ }^{18} \mathrm{~F}$-fluoride uptake and progression of coronary artery calcification. Circ Cardiovasc Imaging 13:e011438. https://doi.org/10.1161/CIRCIMAGING.120.011438 
24. Niccoli Asabella A, Ciccone MM, Cortese F, Scicchitano P, Gesualdo M, Zito A, Di Palo A, Angiletta D, Regina G, Marzullo A, Rubini G (2014) Higher reliability of 18F-FDG target background ratio compared to standardized uptake value in vulnerable carotid plaque detection: a pilot study. Ann Nucl Med 28:571579. https://doi.org/10.1007/s12149-014-0850-9

25. Iwatsuka R, Matsue Y, Yonetsu T, O'uchi T, Matsumura A, Hashimoto Y, Hirao K (2018) Arterial inflammation measured by ${ }^{18} \mathrm{~F}$-FDG-PET-CT to predict coronary events in older subjects. Atherosclerosis 268:49-54. https://doi.org/10.1016/j.atherosclerosis.2017.11.016

26. Johnsrud K, Skagen K, Seierstad T, Skjelland M, Russell D, Revheim ME (2019) 18F-FDG PET/CT for the quantification of inflammation in large carotid artery plaques. J Nucl Cardiol 26:883-893. https://doi.org/10.1007/s12350-017-1121-7

27. Choi YS, Youn HJ, Chung WB, Hwang HJ, Lee DH, Park CS, Lee JB, Kim PJ, Chung WS, Lee MY, Seung KB, Chung YA (2011) Uptake of F-18 FDG and ultrasound analysis of carotid plaque. J Nucl Cardiol 18:267-272. https://doi.org/10.1007/s12350-011-9338-3

28. Hetterich H, Rominger A, Walter L, Habs M, Volpers S, Hacker M, Reiser MF, Bartenstein P, Saam T (2016) Natural history of atherosclerotic disease progression as assessed by (18)F-FDG PET/CT. Int J Cardiovasc Imaging 32:49-59. https://doi.org/10.1007/s10554-015-0660-8

\section{Figures}

1157 patients with suspected lung cancer underwent 18F-FDG PET

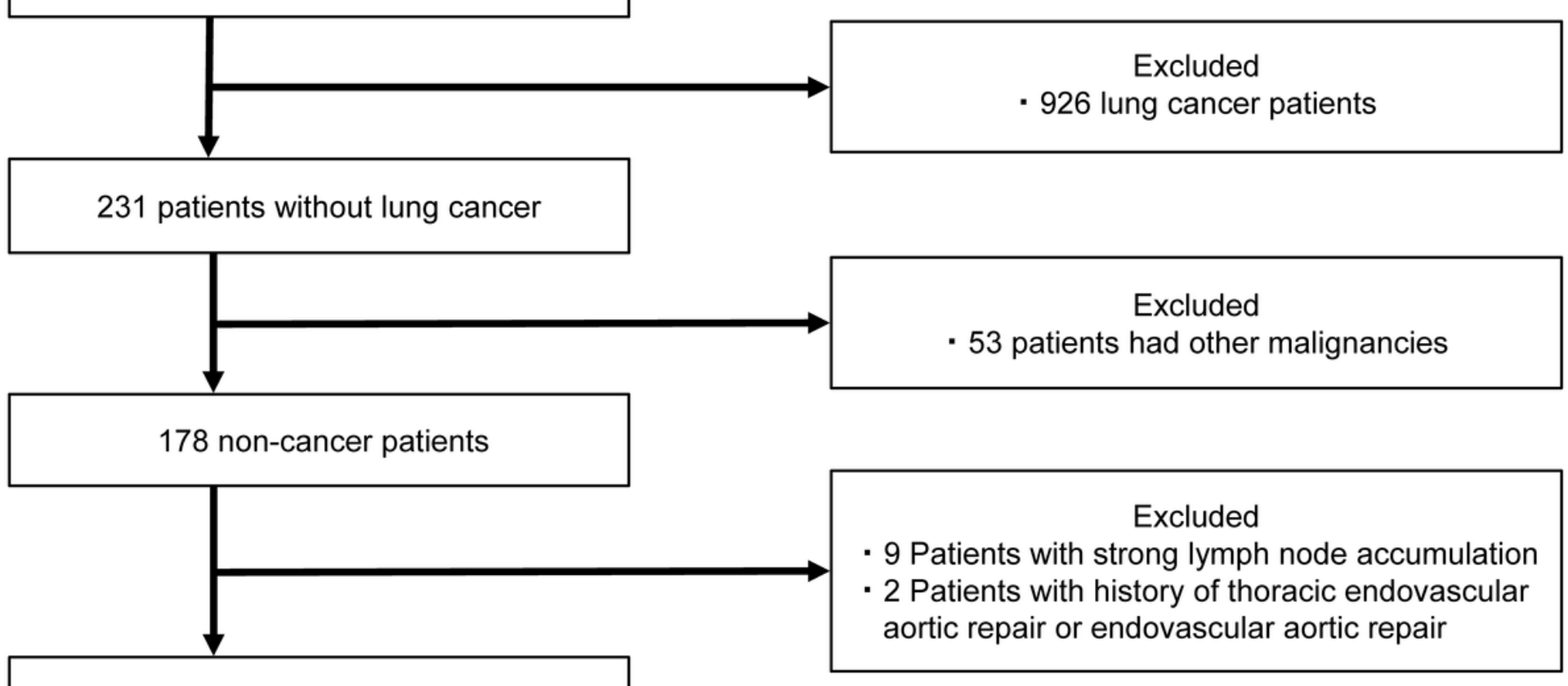

167 patients 


\section{Figure 1}

Flow chart of the study

Abbreviations: $18 \mathrm{~F}-\mathrm{FDG}$ PET, ${ }^{18} \mathrm{~F}$-fluorodeoxyglucose positron emission tomography

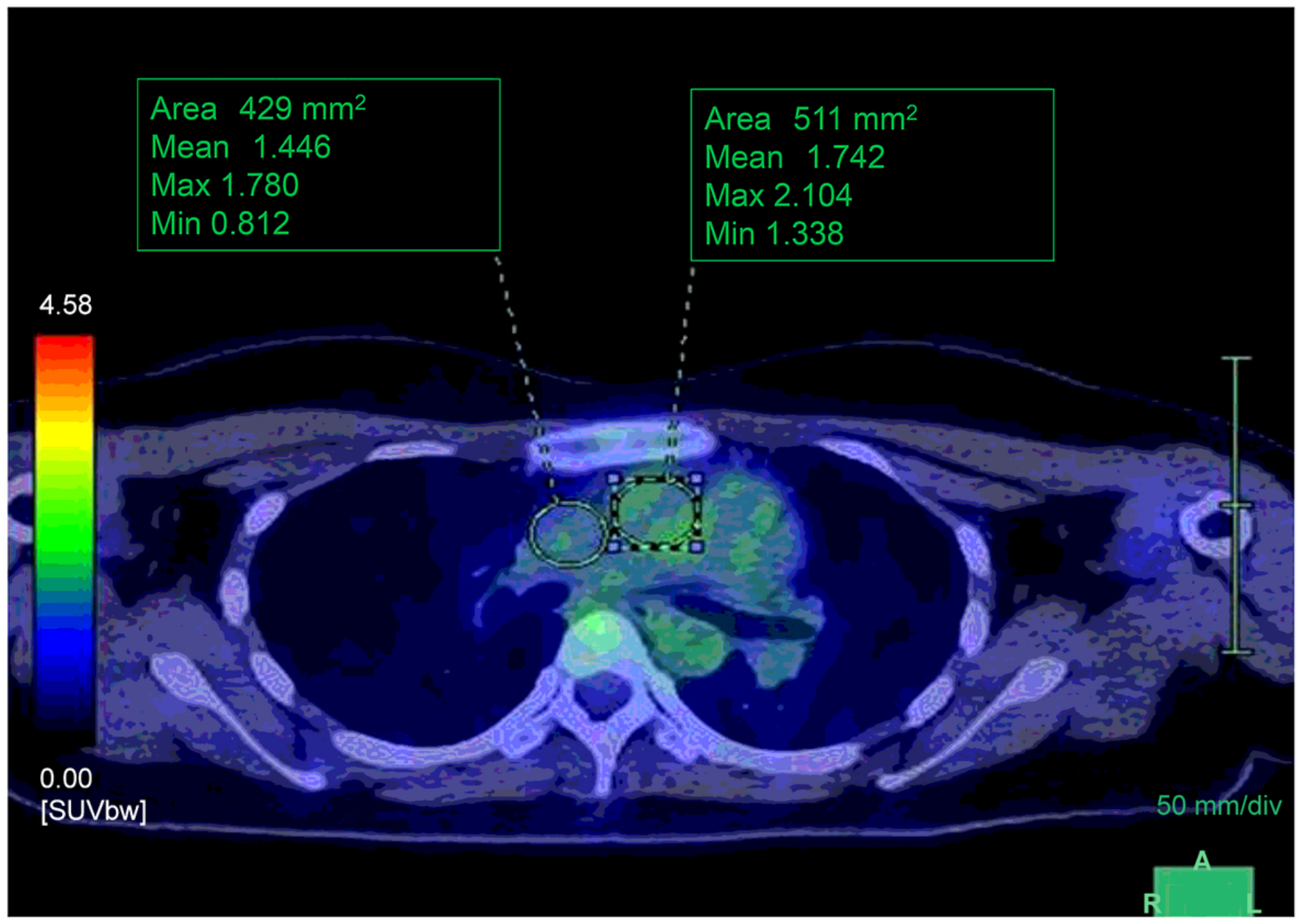

\section{Figure 2}

Image measuring standardized uptake values (SUV) 